\title{
Potensi Bawang Putih dan Lactobacillus achidophilus sebagai Sinbiotik terhadap Karakteristik Tulang Ayam Broiler
}

\author{
Potency of Garlic and Lactobacillus acidophilus as Sinbiotic on Broiler Chicken Bone \\ Characteristics
}

\author{
N. E. Aurora, L. D. Mahfudz dan T. A. Sarjana \\ Fakultas Peternakan dan Pertanian, Universitas Diponegoro \\ Corresponding e-mail: 1mahfudz@gmail.com
}

\begin{abstract}
The aim of this research was to examine the synbiotic interactions of garlic (Alium sativum) and Lactobacillus achidophilus on the characteristics of broiler chicken bones. The material used was 144 broiler chickens strain Cobb unsexed 7 days old with initial body weight $45.68 \pm 1.52 \mathrm{~g}$, in a completely randomized design with 3 treatments and 8 units each unit consisting of 6 birds. Treatments applied of addition synbiotic was T0: control feed (without synbiotics); T1: control feed $+2 \mathrm{ml}$ synbiotic; T2: control feed $+4 \mathrm{ml}$ synbiotic. Parameters observed were the length and weight of the tibia, femur, bone strength and bone $\mathrm{Ca}$ mass. The data were statistically analyzed by Analysis of varince with $\mathrm{F}$ test and if there significantly effected by tretment, continues by Duncan test. The results show that the use of synbiotics up to $4 \mathrm{ml}$ level did not significantly $(\mathrm{P}>0.05)$ to the length of the femur, tibia and femur weight, and calcium mass, but significantly increased $(\mathrm{P}<0.05)$ tibia length, tibia and femur bone strength. The conclusion is synbiotic extract from garlic extract and Lactobacillus achidophilus as much as $2 \mathrm{ml} / \mathrm{kg}$ ration in broiler chicken rations is enough to improve the characteristics of broiler chicken bones.
\end{abstract}

Key words: broiler chicken, sinbiotic, garlic extract, Lactobacillus acidophilus, tibia bones, femur bones, calcium bone mass

\begin{abstract}
ABSTRAK
Penelitian ini bertujuan untuk mengkaji pengaruh sinbiotik dari bawang putih (Alium sativum) dan Lactobacillus achidophilus terhadap karakteristik tulang ayam broiler. Materi yang digunakan sebanyak 144 ekor ayam broiler strain Cobb unsex umur 7 hari dengan bobot badan 218,5 \pm 8,87 gram, dalam rancangan acak lengkap (RAL) dengan 3 perlakuan dan 8 ulangan setiap unit percobaan terdiri dari 6 ekor. Perlakuan yang diberikan yaitu T0 : pakan kontrol (tanpa penambahan sinbiotik); T1 : pakan kontrol $+2 \mathrm{ml}$ sinbiotik; T2 : pakan kontrol $+4 \mathrm{ml}$ sinbiotik. Parameter yang diamati meliputi panjang dan bobot tulang tibia, femur, kekuatan tulang dan masa $\mathrm{Ca}$ tulang. Data yang diperoleh dianalisis statistik dan data yang menunjukkan pengaruh perlakuan yang nyata di uji lanjut dengan uji wilayah Duncan. Hasil penelitian menunjukkan bahwa penggunaan sinbiotik hingga taraf $4 \mathrm{ml}$ tidak berpengaruh nyata $(\mathrm{P}>0,05)$ terhadap panjang femur, bobot tibia dan femur, serta massa kalsium, namun nyata meningkatkan $(\mathrm{P}<0,05)$ panjang tibia, kekuatan tulang tibia dan femur. Kesimpulannya adalah penambahan sinbiotik dari ekstrak bawang putih dan Lactobacillus achidophilus sebanyak $2 \mathrm{ml} / \mathrm{kg}$ ransum dalam ransum ayam broiler sudah cukup mampu untuk memperbaiki karakteristik tulang ayam broiler.
\end{abstract}

Kata kunci: ayam broiler, sinbiotik, bawang putih, Lactobacillus achidophilus, tulang tibia, tulang femur, masa kalsium tulang

\section{PENDAHULUAN}

Ayam broiler mampu tumbuh cepat hingga bobot badan tertentu dalam waktu yang singkat namun daya tahan ayam broiler rendah. Peternak ayam broiler biasanya menggunakan antibiotic growth promoter (AGP) untuk meningkatkan imunitas tubuh ayam broiler terhadap virus dan bakteri pathogen. Penggunaan AGP pada ayam broiler dikhawatirkan dapat meninggalkan residu pada karkas dan akan berdampak negatif pada konsumen, oleh karena itu dicari feed aditive alternative selain antibiotik, salah satunya adalah probiotik, prebiotik serta kombinasi probiotik dan prebiotik yang sering disebut dengan sinbiotik. Sinbiotik merupakan kombinasi antara probiotik dan prebiotik yang mampu menjadi alternative pengganti antibiotik, yang mana dapat 
menstimulasi pertumbuhan dan meningkatkan daya tahan serta memperbanyak mikroba probiotik di dalam saluran pencernaan (Goubeyer et al., 2010).

Bawang putih diduga dapat mengoptimalkan fungsi saluran pencernaan dan metabolisme sehingga penggunaan pakan menjadi lebih efisien. Berdasarkan hasil pengujian, bawang putih mengandung fruktooligosakarida (FOS) sebanyak 3,34\% (Sunu et al., 2019) sehingga bawang putih dapat dijadikan sebagai prebiotik. Kandungan fruktooligosakarida (FOS) merupakan senyawa karbohidrat rantai sedang atau yang dikenal sebagai prebiotik dan dapat menjadi sumber nutrient probiotik.

Bawang putih juga mengandung fitobiotik yang disebut dengan allicin. Allicin bersifat bakteriostatik yaitu mampu menembus dinding sel bakteri sehingga struktur dinding sel bakteri rusak dan bakteri akan mati. Bawang putih dapat digunakan sebagai sumber nutrisi untuk Lactobacillus achidophilus karena bakteri ini tahan terhadap allicin.

Lactobacillus achidophilus dapat dikombinasikan dengan bawang putih menjadi sinbiotik. Lactobacillus acidophilus mampu menempel dengan kuat pada usus (Sumarsih, et al., 2012). Kelebihan dari Lactobacillus achidophilus yaitu selain tahan terhadap allicin, juga mampu memanfaatkan fruktosa dari bawang putih sebagai sumber nutrisi. Hasil penelitian Cahyono et al. (2019) menunjukkan bahwa pemberian Lactobacillus achidophilus mampu meningkatkan bobot tulang femur secara signifikan yaitu dari $9 \mathrm{~g}$ menjadi $10 \mathrm{~g}$ namun tidak signifikan pada tulang tibia, pemberian Lactobacillus achidophilus juga mampu meningkatkan masa Ca tulang ayam broiler dari $1,78 \mathrm{~g}$ menjadi $2,41 \mathrm{~g}$.

Penambahan sinbiotik dari ekstrak bawang putih dan Lactobacillus achidophilus dalam ransum ayam broiler dapat meningkatkan populasi bakteri asam laktat (BAL) dan produksi asam laktat. Meningkatnya populasi bakteri asam laktat (BAL) dalam usus dapat menurunkan $\mathrm{pH}$ dalam saluran pencernaan dan menekan bakteri patogen dan mengaktifkan enzim enzim pencernaan (Hartono et al., 2016). Saluran pencernaan akan menjadi lebih sehat yang kemudian perkembangan vili usus akan meningkat, sehingga kecernaan dan penyerapan nutrisi meningkat terutama protein dan kalsium (Purwati et al., 2005). Diketahui bahwa protein dan kalsium diserap dalam usus halus secara bersamaan. Kecernaan dan penyerapan kalsium didukung dengan $\mathrm{pH}$ saluran pencernaan yang rendah, karena kecernaan dan penyerapan kalsium membutuhkan kondisi asam. $\mathrm{pH}$ rendah pada saluran pencernaan akan meningkatkan kecernaan kasium..

Nilai massa $\mathrm{Ca}$ Tulang seiring dengan nilai retensi $\mathrm{Ca}$, yang diimbangi dengan peningkatan deposisi $\mathrm{Ca}$ dalam tulang (Maghfiroh et al., 2014). Semakin tinggi retensi $\mathrm{Ca}$ berarti semakin tinggi $\mathrm{Ca}$ yang diserap (Barreiro et al., 2011). Pertumbuhan yang paling cepat adalah tulang dan setelah tercapai ukuran maksimal maka pertumbuhan akan terhenti. Meningkatnya panjang tulang, berat tulang dan masa $\mathrm{Ca}$ merupakan cerminan tingginya masa $\mathrm{Ca}$ tulang.

Dibandingkan tulang tibia, tulang femur lebih sensitif terhadap perubahan ransum (Dilworth dan Day, 1965), meskipun demikian mineralisasi tulang femur terjadi lebih lambat dibandingkan dengan tulang tibia sehingga tulang femur diduga sebagai penyebab abnormalitas perkembangan panjang tulang (Hastuti et al., 2013). Pemberian sumber Ca dan $\mathrm{P}$ berkaitan dengan pertumbuhan tulang tibia. Kalsium yang diserap oleh tubuh $98 \%$ disimpan di dalam tulang dan $2 \%$ di dalam cairan ekstra seluler (Murwani, 2010). Deposisi kalsium yang meningkat maka panjang dan bobot tulang tibia dan femur serta massa $\mathrm{Ca}$ tulang ayam broiler juga akan meningkat.

Tujuan dari penelitian ini yaitu mengkaji dampak penambahan sinbiotik dari ekstrak bawang putih (Alium sativum) dan Lactobacillus achidophilus sebagai sinbiotik terhadap bobot dan panjang serta massa Ca pada tulang tibia dan femur. Manfaat dari penelitian ini yaitu mendapat informasi dan pengetahuan mengenai penambahan sinbiotik dari ekstrak bawang putih (Alium sativum) dan Lactobacillus achidophilus sebagai sinbiotik terhadap bobot dan panjang serta massa $\mathrm{Ca}$ pada tulang tibia dan femur. Hipotesis dari penelitian ini yaitu penambahan sinbiotik dari ekstrak bawang putih (Alium sativum) dan Lactobacillus achidophilus dengan taraf $2 \mathrm{ml}$ dan $4 \mathrm{ml}$ dari ransum dapat meningkatkan panjang dan bobot tulang tibia dan femur serta massa Ca pada tulang tibia dan femur ayam broiler.

\section{MATERI DAN METODE}

Penelitian menggunakan 144 ekor ayam broiler strain Cobb unsex umur 7 hari dengan 
bobot badan 218,5 $\pm 8,87$ gram. Metode pembuatan sinbiotik dilakukan berdasarkan metode Sunu et al. (2019) yaitu dengan membuat ekstrak bawang putih jenis kating yang kemudian disaring dan sisterilkan dengan metode pasteurisasi selama 10 menit. Ekstrak bawang putih diletakkan di dalam wadah lalu disimpan pada tempat tertutup dengan suhu $<20^{\circ} \mathrm{C}$. Tahap selanjutnya, ekstrak bawang putih sebanyak 100 $\mathrm{ml}$ dicampurkan dengan Lactobacillus achidophilus sebanyak $1 \mathrm{ml}$ dengan total bakteri $10^{7} \mathrm{cfu} / \mathrm{ml}$, serta isolat yang digunakan yaitu MRS gliserol 20\%. Kultur bateri diremajakan pada media MRS agar, kemudian diinkubasi pada suhu $37^{\circ} \mathrm{C}$ selama 24-48 jam untuk mengaktifkan bakteri. Kemudian diinokulasikan pada media MRS broth sebanyak 1 oose dan diinkubasi pada suhu $37^{\circ} \mathrm{C}$ selama 24 jam.

Ransum penelitian terdiri dari jagung, bekatul, tepung ikan, bungkil kedelai dan premix kemudian dicampur dengan sinbiotik dengan perbandingan $1 \mathrm{~kg}$ ransum : $1 \mathrm{ml}$ sinbiotik. Pakan diberikan ad libitum. Komposisi dan kandungan nutrien ransum tertera pada Tabel 1.

Tabel 1. Komposisi dan kandungan nutrien ransum ayam broiler

\begin{tabular}{ll}
\hline Bahan Pakan & $\begin{array}{l}\text { Komposisi Ransum } \\
(\%)\end{array}$ \\
\hline Jagung & 51,50 \\
Dedak & 15,00 \\
Bungkil Kedelai & 23,00 \\
Tepung Ikan & 10,00 \\
Premiks & 0,50 \\
\hline Total & 100,00 \\
\hline EM (kkal/kg)** & $3.051,00$ \\
PK (\%)* & 22,01 \\
LK (\%)* & 6,20 \\
SK (\%)* & 4,36 \\
Ca (\%)* & 1,99 \\
P (\%)* & 1,08 \\
Arginin (\%)* & 1,29 \\
Methioni (\%)* & 0,49 \\
Lisin (\%)* & 1,21 \\
\hline
\end{tabular}

(*) Hasil analisis proksimat

$(* *)$ Nilai Energi Metabolis (EM) dihitung

berdasarkan rumus Bolton sebagaimana digunakan dalam Sugiharto et al. (2017)

Rancangan penelitian yang digunakan adalah rancangan acak lengkap (RAL) yang terdiri dari 3 perlakuan dan 8 ulangan dengan 6 ekor ayam disetiap unit percobaan. Perlakuan yang diberikan adalah penambahan sinbiotik pada ransum sebagai berikut berikut :

T0 : Tanpa penambahan sinbiotik (kontrol)

T1 : Penambahan sinbiotik $2 \mathrm{ml} / \mathrm{kg}$ dari ransum

$\mathrm{T} 2$ : Penambahan sinbiotik $4 \mathrm{ml} / \mathrm{kg}$ dari ransum

Parameter yang diamati yaitu karakteristik tulang pada saat ayam berumur 42 hari meliputi panjang dan berat tulang tibia dan femur serta masa $\mathrm{Ca}$ tulang ayam broiler. Penimbangan berat tulang femur dan tibia dilakukan dengan menggunakan timbangan analitik ketelitian 0,0001 g (Bangun, 2013). Panjang tulang femur dan tibia diukur pada kondisi tulang terpisah dari daging dan dinyatakan dalam satuan cm (Rizkuna, 2014). Kekuatan tulang diambil dari hasil pengujian melalui kekuatan putus tulang pada tulang tibia dan femur ayam broiler menggunakan alat eggshell strength yang ditelah dimodifikasi diuji dengan menghitung besaran gaya yang mampu ditahan oleh tulang hingga patah dan dinyatakan dalam satuan $\mathrm{N} / \mathrm{mm}^{2}$ (Oikeh et al., 2019). Gaya yang diberikan diukur berdasarkan besar beban dan luas penampang permukaan yang digunakan untuk menekan tulang hingga patah.

Massa Ca tulang di ukur pada ayam umur 42 hari dengan campuran sampel tulang tibia dan femur yang telah dipisah dari daging kemudian dikeringkan dan selanjutnya ditumbuk dan dianalisiskan kadar Ca. Perhitungan massa Ca tulang dengan menggunakan formula Farrel (1978), dengan rumus sebagai berikut:

Massa Ca tulang $(\mathrm{g})=\mathrm{Ca}$ tulang $(\%) \times$ Bobot tulang $(\mathrm{g})$

Data hasil penelitian dianalisis ragam pada taraf $p<5 \%$ untuk mengetahui pengaruh perlakuan. Data dari perlakuan yang menunjukkan pengaruh nyata diuji dengan uji Duncan.

\section{HASIL DAN PEMBAHASAN}

Hasil analisis ragam dari pengaruh penggunaan sinbiotik hingga taraf pemberian 4 $\mathrm{ml} / \mathrm{kg}$ ransum terhadap panjang dan bobot tulang tibia dan femur serta massa kalsium tulang ayam broiler dapat dilihat pada Tabel 2. Penggunaan sinbiotik pada taraf $2 \mathrm{ml} / \mathrm{kg}$ ransum mampu meningkatkan panjang dan kekuatan tulang 
Tabel 2. Pengaruh perlakuan terhadap panjang dan bobot tulang tibia dan femur serta massa kalsium tulang ayam broiler

\begin{tabular}{lllrrrr}
\hline Parameter & Tulang & Satuan & \multicolumn{1}{c}{ T0 } & \multicolumn{1}{c}{ T1 } & \multicolumn{1}{c}{ T2 } & \multicolumn{1}{c}{ P } \\
\hline Panjang & Femur & Cm & 7,37 & 7,62 & 7,62 & 0,34 \\
& Tibia & Cm & $10,25^{\mathrm{b}}$ & $10,56^{\mathrm{a}}$ & $10,65^{\mathrm{a}}$ & 0,03 \\
Bobot & Femur & G & 11,37 & 12,37 & 12,37 & 0,40 \\
& Tibia & G & 18,14 & 17,62 & 17,12 & 0,67 \\
Massa Kalsium & & G & 4,13 & 4,75 & 4,62 & 0,28 \\
\hline
\end{tabular}

Superskrip berbeda pada baris yang sama menunjukkan perbedaan yang nyata $(\mathrm{P}<0,05)$

femur dan tibia secara signifikan $(\mathrm{P}<0,05)$, meskipun demikian peningkatan penggunaan sinbitiok dari taraf $2 \mathrm{ml} / \mathrm{kg}$ ransum menjadi 4 $\mathrm{ml} / \mathrm{kg}$ ransum tidak mengakibatkan peningkatan panjang tulang tibia, kekuatan tulang femur dan tibia secara lebih lanjut. Pemberian sampai pada taraf $4 \mathrm{ml} / \mathrm{kg}$ ransum tidak memberikan pengaruh signifikan $(\mathrm{P}>0,05)$ terhadap panjang tulang femur, bobot tulang femur dan tibia, serta massa kalsium tulang.

Panjang tulang femur dan tibia masih dalam kisaran normal namun bobot tulang femur dan tibia cenderung lebih tinggi daripada ratarata panjang dan bobot normal tulang femur dan tibia ayam broiler umur 42 hari. Hasil penelitian Applegate dan Lilburn (2002) menunjukkan bahwa rata-rata panjang tulang femur pada usia 42 hari yaitu $5-8 \mathrm{~cm}$ dan pada tulang tibia yaitu $8-11 \mathrm{~cm}$, sedangkan rata-rata bobot tulang femur pada umur 42 hari yaitu $7-9 \mathrm{~g}$ dan tulang tibia yaitu $7-11 \mathrm{~g}$.

\section{Panjang Tulang}

Peningkatan panjang tulang tibia dan femur akibat pemberian sinbiotik diduga disebabkan oleh peran sinbiotik yang mampu meningkatkan fungsi saluran pencernaan dan penyerapan $\mathrm{Ca}$ dan protein. Peningkatan panjang tulang tibia secara prinsip dipengaruhi oleh beberapa alasan, salah satunya peningkatan fungsi saluran pencernaan sehingga mampu meningkatkan kecernaan kalsium akibat penurunan $\mathrm{pH}$. Penggunaan sinbiotik dari kombinasi Lactobacillus achidophilus dan ekstrak bawang putih memiliki kemampuan mengubah karbohidrat untuk diubah menjadi asam laktat.

Hal ini dibuktikan dengan penelitian yang dilakukan oleh Sunu et al., (2019) yang menunjukkan hasil bahwa $\mathrm{pH}$ usus mengalami penurunan akibat dari pemberian sinbiotik yaitu berkisar 6,4-6,7. Penurunan nilai $\mathrm{pH}$ ini disebabkan oleh peningkatan jumlah BAL dalam saluran pencernaan. Hal ini sesuai dengan pendapat Krismiyanto et al. (2014) yang menyatakan bahwa peningkatan BAL ini dapat menurunkan populasi Escheria coli dan menurunkan kadar $\mathrm{pH}$ menjadi sekitar 5,6-6,5 pada saluran pencernaan. Peningkatan fungsi saluran pencernaan ini seiring dengan peningkatan penyerapan protein dan Ca. Penyerapan protein yang tinggi akan memberikan kontribusi terhadap peningkatan penyerapan kalsium, karena protein dan kalsium secara bersamaan diserap dalam usus halus.

Hal ini sesuai dengan pendapat Syafitri, et al. (2015) yang menyatakan bahwa mekanisme yang terjadi yaitu protein akan membawa kalsium ke dalam sel mukosa usus atau yang sering disebut juga dengan calcium binding protein $(\mathrm{CaBP})$, kemudian diangkut ke darah dan diedarkan ke tubuh lalu masuk ke jaringan yang membutuhkan seperti tulang dan daging. Kalsium yang diserap oleh tubuh sebagian besar akan disimpan dalam tulang dan digunakan sebagai komponen penyusun matriks tulang. Hal ini sesuai dengan pendapat Murwani (2010) yang menyatakan bahwa 98\% kalsium yang diserap oleh tubuh disimpan dalam tulang dan $2 \%$ di dalam cairan ekstra seluler. berdasarkan hal tersebut kami menduga bahwa kecukupan ketersediaan komponen penyusun matriks tulang ini menyebabkan tulang tibia mengalami peningkatan yang signifikan.

Protein merupakan komponen yang sangat berperan penting pada proses pertumbuhan tulang, sehingga semakin banyak protein terserap semakin panjang tulang. Pada penelitian ini dampak sigfinikan hanya terjadi pada tulang tibia karena proses mineralisasi pada tulang femur berjalan lebih lambat. Hal ini sesuai dengan hasil penelitian Hastuti, et al (2013) yang menyatakan bahwa mineralisasi pada tulang femur lebih lambat. Hasil penelitian SanchezRodriguez et al. (2019) menunjukan bahwa tulang tibia merupakan salah satu tulang yang paling termineralisasi dalam kerangka dan juga merupakan indikator untuk keseluruhan 
mineralisasi tulang. Berdasarkan hal tersebut, maka peningkatan panjang tulang tibia secara signifikan pada penelitian ini disebabkan karena peningkatan fungsi saluran pencernaan mampu meningkatkan efektifitas kerja $\mathrm{CaBP}$ sehingga meningkatkan kecernaan $\mathrm{Ca}$ dan protein sebagai komponen penyusun matrik tulang.

\section{Bobot Tulang}

Bobot tulang tibia dan femur tidak mengalami peningkatan yang signifikan diduga disebabkan karena sudah terjadi perubahan struktur matriks penyusun tulang akibat peningkatan penyerapan $\mathrm{Ca}$ dan protein, namun belum sampai mempengaruhi bobot tulang. Hal ini akan mempengaruhi kemampuan deposisi $\mathrm{Ca}$ untuk pembentukan matriks tulang. Hasil penelitian Li et al. (2012) menunjukkan bahwa asupan $\mathrm{Ca}$ yg tinggi dapat meningkatkan bobot tulang karena pengendapan $\mathrm{Ca}$ akibat deposisi $\mathrm{Ca}$ pada tulang akan meningkat pula. Kemampuan deposisi ini menyebabkan perubahan struktur matriks tulang. Peningkatan kemampuan mencerna protein juga memberikan kontribusi pada pembentukan matriks kolagen. Kolagen merupakan protein pengikat kalsium yang berfungsi sebagai pembawa kalsium untuk dideposisikan ke dalam tulang. Pembentukan matriks kolagen ini akan berfungsi mengikat $\mathrm{Ca}$ lebih baik. Berdasarkan hal tersebut maka peningkatan kecernaan protein diikuti dengan asupan protein dan $\mathrm{Ca}$ terjadi akibat aksi sinbiotik, namun demikian, peneliti menduga peningkatan perbaikan kecernaan dan penyerapan protein terjadi lebih domninan, sehingga hanya berpengaruh terhadap peningkatan panjang, tidak sampai berpengaruh terhadap bobot meskipun sudah terjadi peningkatan kalsium dan fosfor.

\section{Kekuatan Tulang}

Hasil analisis ragam dari pengaruh penggunaan sinbiotik berupa kombinasi Lactobacillus achidophilus dan ekstrak bawang putih (Alium sativum) hingga pada taraf pemberian $4 \mathrm{ml} / \mathrm{kg}$ ransum terhadap kekuatan tulang tibia dan femur ayam broiler dapat dilihat pada Tabel 3. Penggunaan sinbiotik berupa kombinasi Lactobacillus achidophilus dan ekstrak bawang putih (Alium sativum) pada taraf $2 \mathrm{ml} / \mathrm{kg}$ ransum mampu meningkatkan kekuatan tulang femur dan tibia secara signifikan $(\mathrm{P}<0,05)$. Penggunaan sinbitiok pada peningkatan taraf penggunaan dari $2 \mathrm{ml} / \mathrm{kg}$ ransum menjadi $4 \mathrm{ml} / \mathrm{kg}$ ransum tidak mengakibatkan kekuatan tulang femur dan tibia secara lebih lanjut. Kekuatan tulang tibia dan femur mengalami peningkatan dan berada di kisaran normal nilai kekuatan tulang. Hal ini sesuai dengan pendapat Sanchez-Rodriguez et al. (2019) yang menyatakan bahwa kekuatan patah tulang pada ayam broiler usia 42 hari berkisar $300-500 \mathrm{~N}$

Peningkatan kekuatan tulang diduga disebabkan karena peningkatan fungsi saluran pencernaan yang mempengaruhi penyerapan $\mathrm{Ca}$ dan protein sehingga menyebabkan perubahan penyusun struktur matriks tulang, yang artinya mampu meningkatkan kekuatan tulang meskipun bobot tulang belum terpengaruh secara signifikan. Hal ini sesuai dengan pendapat Siahaan et al. (2014) yang menyatakan bahwa semakin tinggi konsentrasi kalsium yang diserap maka semakin tinggi aktivitas enzim Ca-ATPase sehingga mobilisasi $\mathrm{Ca}$ tulang semakin meningkat, meningkatnya mobilisasi tulang ini menyebabkan proses mineralisasi matriks tulang juga meningkat yang akan mempengaruhi kekuatan tulang. Selain penyerapan $\mathrm{Ca}$ dan protein, perubahan penyusun struktur matriks tulang juga dipengaruhi oleh solubilitas fosfor sehingga kecernaan fosfor meningkat. Solubilitas fosfor diperoleh dari kemampuan probiotik dalam menghasilkan produk fermentasi. Hal ini sesuai dengan pendapat Nari et al. (2020) yang menyatakan bahwa probiotik memproduksi produk fermentasi berupa butyric acid yang dapat mempengaruhi solubilitas fosfor sehingga kecernaan fosfor meningkat. Hasil penelitian Siahaan et al. (2014) menunjukan bahwa proses pengendapan mineral berupa fosfor dalam matriks tulang mampu mempengaruhi kepadatan, kekuatan dan struktur tulang.

Tabel 3. Pengaruh perlakuan terhadap kekuatan tulang tibia dan femur ayam broiler

\begin{tabular}{|c|c|c|c|c|c|c|}
\hline Parameter & & Satuan & T0 & $\mathrm{T} 1$ & $\mathrm{~T} 2$ & $\mathrm{P}$ \\
\hline \multirow[t]{2}{*}{ Kekuatan tulang } & Femur & $\mathrm{N} / \mathrm{mm}^{2}$ & $612,13^{\mathrm{b}}$ & $980,66^{\mathrm{a}}$ & $1105,59^{a}$ & 0,00 \\
\hline & Tibia & $\mathrm{N} / \mathrm{mm}^{2}$ & $487,20^{\mathrm{b}}$ & $812,00^{\mathrm{a}}$ & $830,80^{\mathrm{a}}$ & 0,00 \\
\hline
\end{tabular}

Superskrip berbeda pada baris yang sama menunjukkan perbedaan yang nyata $(\mathrm{P}<0,05)$ 
Berdasarkan hal tersebut, maka peningkatan kekuatan tulang disebabkan peningkatan penyerapan $\mathrm{Ca}$, protein dan fosfor yang menyebabkan perubahan matriks penyusun tulang.

Perbaikan fungsi saluran pencernaan yang disebabkan oleh penambahan sinbiotik pada ransum juga mampu meningkatkan kemampuan pelepasan faktor modulasi tulang seperti fitoesterogen yang akan mempengaruhi kekuatan patah tulang ayam broiler. Penyerapan mineral yang terikat dengan asam fitat akan melepaskan faktor modulasi tulang, salah satunya fitoesterogen. Kandungan FOS pada prebitoik mampu meningkatkan efek dari fitoesterogen untuk kekuatan tulang.. Hal ini berpotensi mampu meningkatkan kekuatan tulang. Hal ini sesuai dengan pendapat Scholz-Ahrens et al. (2007) yang menyatakan bahwa pelepasan faktor modulasi tulang seperti fitoestrogen merupakan salahsatu mekanisme pengaruh dari sinbiotik, efek ini ditunjukan melalui peningkatan bioavailabilitas isoflavon. Stimulasi Lactobacillus oleh FOS meningkatkan aktivitas bakteri luminal b-glikosidase, yang disebut juga enzim yang menghidrolisis glikosidik ikatan konjugat isoflavon. Berdasarkan hal tersebut, maka peningkatan kekuatan tulang secara signifikan pada penelitian ini disebabkan karena penambahan sinbiotik pada ransum yang menyebabkan peningkatan penyerapan $\mathrm{Ca}$, protein dan fosfor serta meningkatkan kemampuan pelepasan faktor modulasi tulang seperti fitoesterogen yang mampu mempengaruhi kekuatan patah tulang ayam broiler.

\section{Massa Kalsium}

Penggunaan sinbiotik dari kombinasi Lactobacillus achidophilus dan ekstrak bawang putih belum memberikan dampak positif terhadap massa kalsium tulang tibia dan femur. Hal ini diduga karena massa $\mathrm{Ca}$ tulang lebih dipengaruhi oleh karakteristik struktur, sedangan panjang dan kekuatan tulang lebih dipengaruhi oleh perubahan dan komposisi struktur tulang. Hal ini ditunjukkan dengan nilai bobot tulang yang tidak berbeda nyata. Salahsatu perubahan karakterikstik tulang yaitu perubahan pada komposisi protein, $\mathrm{Ca}$, dan fosfor. Hal ini sesuai dengan pendapat Siahaan et al., (2014) yang menyatakan bahwa proses kalsifikasi tulang merupakan proses pengendapan mineral terutama kalsium dan fosfor dalam matriks tulang yang mampu mempengaruhi kepadatan, kekuatan dan struktur tulang. Bobot tulang yang tidak berbeda nyata namun panjang dan kekuatan tulang yang berbeda nyata membuktikan bahwa peningkatan penyerapan protein tulang mampu meningkatkan pembentukan kolagen sehingga meningkatkan kekuatan tulang, namun perubahan matriks tulang tersebut belum mempengaruhi perubahan massa Ca secara keseluruhan.

\section{KESIMPULAN}

Penambahan sinbiotik dari ekstrak bawang putih dan Lactobacillus achidophilus pada taraf $2 \mathrm{ml} / \mathrm{kg}$ ransum ayam broiler mampu meningkatkan panjang tulang tibia, kekuatan tulang tibia dan kekuatan tulang femur meskipun belum mampu mempengaruhi bobot tulang tibia dan femur serta massa kalsium tulang. Penggunaan sinbiotik menjadi $4 \mathrm{ml} / \mathrm{kg}$ ransum tidak mengakibatkan peningkatan panjang tulang tibia serta kekuatan tulang femur dan tibia secara lebih lanjut. Kesimpulan dari penelitian ini yaitu penggunaan sinbitiok $2 \mathrm{ml} / \mathrm{kg}$ sudah cukup untuk memperbaiki karakteristik tulang ayam broiler.

\section{DAFTAR PUSTAKA}

Applegate, T. J. and M. S. Lilburn. 2002. Growth of the femur and tibia of a commercial broiler line. Poultry Science 81 (9): 1289-1294.

Bangun, G. D. D., L. D. Mahfudz dan D. D. Sunarti, D. D. 2013. Pengaruh penggunaan tepung rumput laut (Gracilaria verrucosa) dalam ransum ayam broiler terhadap berat dan ukuran tulang tibia dan tarsometatarsus. Animal Agricultural Journal 2(1): 489-496.

Barreiro, F. R., S.M.B. Artoni, L. A. Amaral, J. C. Barbosa, A. M. Girardi, M. R. Pacheco, L. Amoroso. 2011. Determination of broiler femur parameters at different growth phases. Int J of Poult Sci. 10 (11): 849-853.

Cahyono S., N. Suthama, B. Sukamto. 2019. Pertumbuhan tulang ayam broiler diberi ransum dengan protein dan kalsium mikropartikel ditambah Lactobacillus acidophilus atau asam sitrateminar. Nasional Sains and Entrepreneurship 1(1): 1-7. 
Setiawati, D., B. Sukamto, H. I. W. 2016. pengimbuhan enzim fitase dalam ransum ayam pedaging meningkatkan pemanfaatan kalsium untuk pertumbuhan tulang dan bobot badan. Jurnal Veteriner 17(3): 468-476.

Dilworth, B. C., and E. J. Day. 1965. Effect of varying dietary calcium:phosphorus ratios on tibia and femur composition of the chick. Poultry Sci. 44:1474-1479.

Gourbeyre, P., S. Denery, and M. Bodinier. 2010. Probiotics, Prebiotics, and Synbiotics: impact on the gut immune system and allergic reactions. Journal of leukocyte biology 89(5): 685-695.

Hartono, E., F., Iriyanti N., dan Suhermiyati S. 2016. Efek penggunaan sinbiotik terhadap kondisi miklofora dan histologi usus ayam sentul jantan. Agripet. 16:(2). 97-105.

Hastuti, D. T., Mahfudz, L. D., dan Sarengat, D. W. 2013. Pengaruh penggunaan tepung buah jambu biji merah dalam ransum terhadap pertumbuhan tulang ayam broiler. Animal Agricultural Journal 2(2): 26-32.

Heravi, R. M., H. Kermanshahi, M. Sankian, M. R. Nassiri, A. Heravi Moussavi, L. Roozabeh Nasiraii, A.R. Varasteh. 2011. Screening of Lactobacilli bacteria isolated from gastrointestinal tract of broiler chickens for their use as probiotic. $A$ frican Journal of Microbiology Research 5(14): 1858-1868.

Krismiyanto, L., Suthama, N., dan Wahyuni, H. I. 2014. Feeding effect of inulin derived from dahlia variabilis tuber on intestinal microbes in starter period of crossbred native chickens. Journal of the Indonesian Tropical Animal Agriculture 39(4): 217223

Leytem, A. B., P. Kwanyuen, and P. Thacker. 2008. Nutrient excretion, phosphorus characterization, and phosphorus solubility in excreta from broiler chicks fed diets containing graded levels of wheat distillers grains with solubles. Poultry Science 87 (12): 2505-2511.
Li, J., Yuan, J., Guo, Y., Sun, Q., and Hu, X. 2012. The influence of dietary calcium and phosphorus imbalance on intestinal $\mathrm{NaPi}$-IIb and calbindin mRNA expression and tibia parameters of broilers. AsianAustralasian Journal of Animal Sciences 25 (4): 552-558.

Maghfiroh, K., B. Sukamto, dan L.D. Mahfudz. 2014. Penggunaan sorgum atau kulit pisang terhidrolisis terhadap retensi kalsium dan massa kalsium tulang pada ayam broiler. J. Agromedia 32 (1): 54-62.

Murwani, R. 2010. Broiler Modern. Widya Karya, Semarang.

N. Nari, H.A. Ghasemi, I. Hajkhodadadi, A.H., K. Farahani. 2020. Intestinal microbial ecology, immune response, stress indicators, and gut morphology of male broiler chickens fed low-phosphorus diets supplemented with phytase, butyric acid, or Saccharomyces boulardii. Livestock Science 234, 1871-1413.

Oikeh, I., P. Sakkas, D. P. Blake, and I. Kyriazakis. 2019. Interactions between dietary calcium and phosphorus level, and vitamin $\mathrm{D}$ source on bone mineralization, performance, and intestinal morphology of coccidiainfected broilers. Poultry Science 98 (11): 5679-5690.

Purwati, E., S. Syukur dan Z. Hidayat. 2005. Lactobacillus $s p$. Isolasi dari Biovicophitomega sebagai probiotik. Lembaga Ilmu Pengetahuan Indonesia, Jakarta.

Rizkuna, A., U. Atmomarsono, dan D. Sunarti. 2014. Evaluasi pertumbuhan tulang ayam kampung umur 0-6 minggu dengan taraf protein dan suplementasi lisin dalam ransum. J. Ilmiah dan Teknologi Peternakan 3(3): 121-125.

Sanchez-Rodriguez, E., Benavides-Reyes, C., Torres, C., Dominguez-Gasca, N., Garcia-Ruiz, A. I., Gonzalez-Lopez, S., and Rodriguez-Navarro, A. B. 2019. Changes with age (from 0 to $37 \mathrm{D}$ ) in 
tibiae bone mineralization, chemical composition and structural organization in broiler chickens. Poultry Science 98 (11): 5215-5225.

Scholz-Ahrens, K. E., Ade, P., Marten, B., Weber, P., Timm, W., Açil, Y., and Schrezenmeir, J. 2007. Prebiotics, Probiotics, and Synbiotics affect mineral absorption, bone mineral content, and bone structure. The Journal of Nutrition 137(3): 838S-846S.

Siahaan, N. B. D. Sunarti. dan V. D. Yunianto. 2014. Pengaruh penggunaan kulit pisang biokonversi dalam ransum terhadap penyerapan kalsium serta kekuatan tulang ayam broiler. Jurnal Ilmu-Ilmu Peternakan 24(3): 18-23

Sugiharto, S., T. Yudiarti and I. Isroli. 2017. Effect of feeding cassava pulp fermented with acremonium charticola on growth performance, nutrient digestibility and meat quality of broiler chick. Journal of Animal Sciene, South African 47 (2): 130-138.

Sumarsih, S., B. Sulistiyanto, C.I. Sutrisno, dan E. S. Rahayu. 2012. Peran probiotik bakteri asam laktat terhadap produktivitas unggas. Jurnal Litbang Provinsi Jawa Tengah 10 (1): 1-9.

Sunu, P., D.Sunarti, L. D. Mahfudz, V. D. Yunianto. 2019. Prebiotic activity of garlic (Allium sativum) extract on Lactobacillus acidophilus. Veterinary World 12 (22): 2046-2051.

Suprapto, W., Kismiyati, S., dan Suprijatna, E. 2012. Pengaruh penggunaan tepung kerabang telur ayam ras dalam ransum burung puyuh terhadap tulang tibia dan tarsus. Animal Agricultural Journal 1(1): 75-90.

Syafitri, Y.E., V. D.Yunianto, and N. Suthama. 2015. Pemberian Ekstrak daun beluntas (Pluchea indica Less) dan klorin terhadap massa kalsium dan massa protein daging pada ayam broiler. Animal Agriculture Journal 4 (1): 155-164.

Talaty, P. N., M. N. Katanbaf, and P. Y. Hester. 2009. Life cycle changes in bone mineralization and bone size traits of commercial broilers. Poultry Science 88 (5): 1070-1077. 